\title{
Balkanologie
}

Balkanologie Revue d'études pluridisciplinaires

Vol. XI, $n^{\circ} 1-2$ | 2008

Volume XI Numéro 1-2

\section{Migrations in the "neighborhood": Negotiations of identities and representations about "Greece" and "Europe" among Bulgarian migrants in Athens}

Aliki Angelidou

\section{OpenEdition}

Journals

Electronic version

URL: http://journals.openedition.org/balkanologie/1152

DOI: 10.4000/balkanologie.1152

ISSN: 1965-0582

Publisher

Association française d'études sur les Balkans (Afebalk)

\section{Electronic reference}

Aliki Angelidou, "Migrations in the "neighborhood": Negotiations of identities and representations about "Greece" and "Europe" among Bulgarian migrants in Athens », Balkanologie [Online], Vol. XI, n 1-2 | 2008, Online since 31 December 2008, connection on 17 December 2020. URL : http:// journals.openedition.org/balkanologie/1152 ; DOI : https://doi.org/10.4000/balkanologie.1152

This text was automatically generated on 17 December 2020.

(c) Tous droits réservés 


\title{
Migrations in the "neighborhood": Negotiations of identities and representations about "Greece" and "Europe" among Bulgarian migrants in Athens
}

\author{
Aliki Angelidou
}

1 The last two decades intense interest has been developed among scholars around the questions of "migration" (Brettell 2003), "diasporas" (Clifford 1994, Brah 1996, Cohen 1997, Vertovec \& Cohen 1999) and "transnationalism". This academic interest is related to phenomena associated with late modernity, such as the inflation and acceleration of the movements of goods, services, information and people around the planet or the reconnection through these processes of places which seemed far remote in the past ${ }^{2}$. This is the case of Bulgaria and Greece, both of which have faced new forms of migration since the end of socialism. The former has known a massive external emigration, a phenomenon practically inexistent during socialism, whilst the latter has been transformed from an emigration to an immigration country, receiving immigrants mainly from Balkan states and the former Soviet Union ${ }^{3}$.

In addition, as several researches have shown, the reopening of the borders after the end of socialist regimes has activated processes of stereotyping and demonizing the "Western" or "Balkan" Other respectively, as an opposite to the Self4. The new increasing trans-border movements at the edges of the European Union, between two neighboring countries that until very recently were separated not only by a national but also by a European border, do not imply only diverse changes of the socioeconomic situation of the persons that move, but are also invested with new meanings and values and signify new ways of defining individual and collective identities ${ }^{5}$. It is thus interesting to explore how the experience of migration permits the confirmation and/ or reevaluation of stereotypes about the Self and the Other in the context of movement 
between two neighboring states that have constructed their image of the (national) Self in opposition and antagonism to each other ${ }^{6}$.

It is in this sense that this paper deals with the perceptions Bulgarian migrants have of "Greece" and "Europe" during their daily interactions with their Greek employers, civil servants and neighbors. Emphasis is placed upon the reconsideration of the images migrants used to have before their arrival to Greece, through the experience of daily life there. More specifically, I explore the reconfigurations of their image of Greece, as a member of the EU and a "wealthy" and "successful" country, on the one hand, but on the other, also as a neighboring country which seems much familiar and similar to Bulgaria. In addition, I look into the impact of these representations on the migrants' ideas about the EU and the negative attitude that most of them adopt towards the ascension procedure. Last call of attention is for the diverse self-images that are activated through the migration process as well as for the new power relations involving both the newcomers and the Greeks.

4 The analysis is based on the material collected through fieldwork research conducted in the area of Athens in 2005-2006, just before Bulgaria's ascension in the $\mathrm{EU}^{7}$. Subsequently, further research was conducted in 2007-2008, after Bulgaria's entry, in an attempt to detect potential changes in practices and representations initiated by this fact. The research was based on fieldwork including participatory observation and interviews with Bulgarian migrants in Athens and the semi-urban area of Marathonas ${ }^{8}$. In contrast to most recent social research on migration in Greece, which draws on quantitative data and on the institutional aspects of the new migration (legislation, official policies and discourse), this anthropological research attempts to turn to the unofficial aspects of migration, focusing on qualitative data and life stories ${ }^{9}$. Thus, by giving voice to the discourse of the migrants themselves it explores the ways in which they perceive both European and Greek society, redefining their identities through the migration process ${ }^{10}$. 
Map 1 - Region of Attica: main places of fieldwork

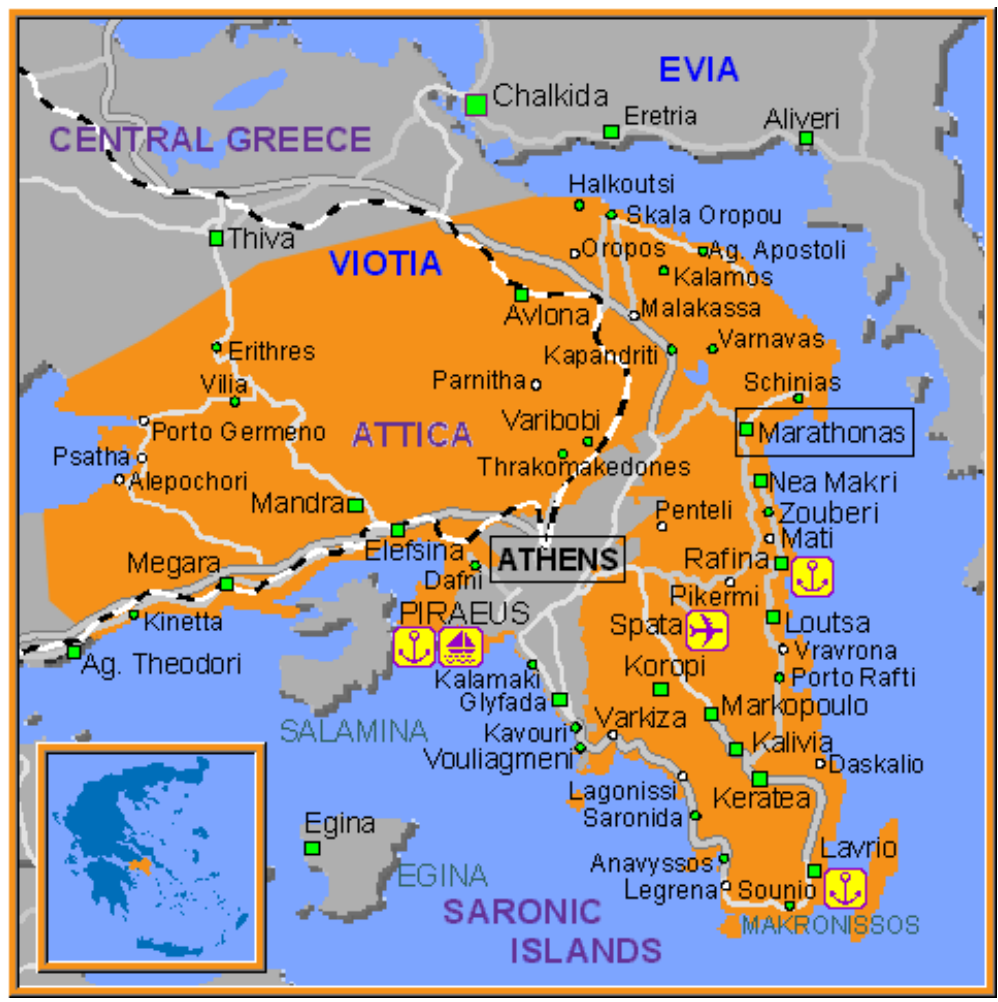

Source : http://www.travel-greece.orgathens_atticaatticamap

\section{The motives of migration and the initial representations about Greece}

In numbers, the Bulgarians are, after the Albanians, the largest migration group in Greece today ${ }^{11}$. Their massive arrival in the country started almost a decade latter than that of the Albanians, at the end of the 1990s and continues until nowadays ${ }^{12}$. Bulgarian migrants in Greece are mainly Christian women ${ }^{13}$ of working age, who move individually, usually leaving their family back. They undertake, legally or illegally, unskilled jobs as agricultural workers, house-cleaners, baby sitters and private nurses for elder people. They also work in restaurants or bars as waitresses, cleaners or cooks and in the entertainment, including sex services ${ }^{14}$.

Concerning the motives of their migration, most Bulgarian immigrants state economical reasons: "We came for the money. That's it" remarks Tanja, 33 years-old. They mention that the basic reason for crossing the borders was the important difference of wages between the two countries. Many of them stress that they would not have come in Greece if this difference did not exist. Consequently, the border signifies economic differences and makes mobility profitable in this case of migration, as in many other cases, since it produces value through economic inequalities that exist on both sides ${ }^{15}$. Some refer to unemployment as a motive for migration but most of them had a job and were owners of a house or apartment in Bulgaria. Nevertheless, the salaries they received were too small to allow themselves and their families to save money or satisfy their needs, such as the education of their children, the maintenance of their 
apartment or, more rarely, the acquisition of a house. So although many of them could be considered as "wealthy", having a job and owning a real estate, they decided to migrate because they perceived themselves as "poor" and insufficient to cope with the demands of the new capitalist way of life.

In addition, they underline that they decided to move in Greece specifically, because of its proximity with Bulgaria, both geographical and cultural: "The two countries are very close regarding the mentality and way of life" remarks Lily, aged 54. For most of them, Greece seemed a nearby country to which they had an easy access and from which they could easily reach back Bulgaria: "I was thinking that in case something happens, I can reach the Bulgarian border even on feet" 34 year-old Mariana notes. So the sense of moving to a familiar and proximate country was a crucial factor determining the choice of Greece in comparison to other EU countries. Many of my younger co-discussants envisaged Greece as a first stop in their movement towards another European country, whilst older ones preferred Greece exactly because of its proximity, as they considered that they were migrating temporarily (although the duration of their stay was not clear to them) and that the movement back and forth between the two counties was possible. Concerning the initial representations about Greece before traveling there, many informants remark that they had few or vague images "I knew nothing about Greece before coming here, only that people come to work and earn good money" Daniela, aged 38, remarks. Few had traveled abroad before their migrant experience, almost exclusively to countries of the ex-socialist block. So most of their images were constructed either through the narratives of relatives, colleagues, or neighbors who had migrated to Greece - or had heard from other people who had done so - or through the various Greek movies and soap operas that pass in the Bulgarian television the last years.

In the narratives they had from their acquaintances, Greece was presented in a stereotypical way as a "wealthy", "developed" and "beautiful" country where "people live well", images in total contradiction to the situation of socio-economic crisis in Bulgaria at that moment. Some of them, the most educated ones, had an idealized image of Greece, associated with the antiquity and with the ancient Greek civilization, drawn from their school education or from their personal readings. In a more general way, most Bulgarian immigrants note that Greece represented for them a country "equivalent" to their own in terms of shape and geopolitical situation but which has met a more successful economic development during the last decades and has profited from generous EU funding: "you have chosen the right camp, we didn't" Valentin, aged 40, notes ${ }^{16}$.

10 Another feature of the Bulgarian migration to Greece is the very little planification regarding the displacement. In their majority, my co-discussants claim that they didn't have any specific program in respect to the place where they were going, the job they would do or the duration of their stay: "I didn't have any initial plan, I just decided one day to live and I left the next" 37 year-old Iva explains. They are giving emphasis to the fact that they envisaged a temporary movement, just to escape a difficult socio-economic situation in their country: "I left for some months to earn some money for repairing our apartment and here I am still in Greece for 9 years now!" 38-year-old Daniela says. No one of my informants left with the idea that s/he wouldn't return to Bulgaria and that $\mathrm{s} / \mathrm{he}$ was leaving in order to be settled permanently to Greece. And nobody made any longterm preliminary preparations, as for example learning Greek before arriving there ${ }^{17}$. 


\section{The transformation of the initial representations through the migration experience in Greece}

\section{The Greek state, the informal networks and the private sector}

11 The very first impressions after the arrival in the "host"-country were positive. As most persons have crossed the borders by bus, in their descriptions they refer to the difference and beauty of the scenery: the sea, the lack of green compared with Bulgaria, the nice weather. They also remark the "order" and "cleanliness" of the landscape: "here all the houses are white and clean, you don't see neither mud, nor dirt as you see in Bulgaria, that is what surprised me most at first" remarks Iva. Furthermore, they describe the Greeks as "open", "spontaneous" and "joyful" people. And, despite the differences, they quickly had a sense of familiarity in their new social environment, especially those who found themselves in rural areas: "I had heard that Greece is a modern and rich county but when I came to Marathonas (a small agricultural town in the suburbs of Athens) I found my village" notes Nadka, aged 46.

12 However, for many migrants the first positive impressions have been followed by a kind of disappointment. Their disappointment and disillusionment is associated with the lack of involvement and assistance, towards them as migrants, from both the Bulgarian and the Greek state. To my question how did you arrive in Greece Liliana replies "by paying and through acquaintances" (s pari $i$ chrez poznati). Most of them collected all the practical information about the trip from relatives and acquaintances who had already migrated and were familiar with the procedures. They traveled with one of the specialized Greek-Bulgarian tourist firms that assure the visa and organize the trip to Greece. Upon their arrival, they have been initially hosted by acquaintances who also helped them to find their first job. Many of them, especially women, underline that the presence of relatives or acquaintances was a decisive factor that oriented them towards Greece. In other cases, they have been settled in one of the hotels reserved for immigrants in the center of Athens and they have been addressed for a job to a specialized office.

13 It becomes clear that the informal networks of support and the personal relations, assisted by the private business sector are the main sources of information. As there is no bilateral agreement between the two countries to provide a framework to this mobility, migrants try to resolve the problems of their movement towards Greece as well as those associated with their residence and their search for a job through these complex networks, in which both Greek and Bulgarians are involved. Since structures of accommodation do not exist, as it is the case in other EU countries, the presence of the state in all these procedures is limited and usually becomes synonym of maltreatment and inefficiency. For all these reasons migrants turn to private sector and to personal contacts to deal with permanent or less permanent hardships in the new country ${ }^{18}$.

Most of the migrants have entered the country with a short-term tourist visa and remained after its expiration. Many have legalized their status in Greece and regularly apply for the actualization of their official documents. Especially for persons that left their family behind, the official documents are of first importance since they can circulate back and forth freely, and this is the reason they seek to have a legitimate status despite the efforts demanded and the important financial cost of the procedure. 
Others, mostly those who envisage their return in Bulgaria in the years to come, prefer to remain undocumented workers as they consider that they don't get any profit from the money they are asked to pay and that the years of work in Greece won't be recognized in Bulgaria once they will return. In addition, many negotiations take place between employer and employee whether the former will pay for social security or not and most, especially women who work as house-cleaners or private nurses, prefer a

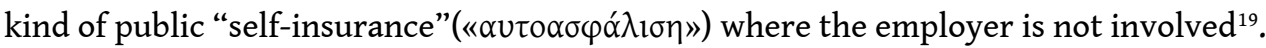

During the first years of their stay they live in an intense state of temporariness, mobility, invisibility and lack of interaction with the state ${ }^{20}$. They are employed at seasonal or short-term jobs, they change frequently place of work and residence, employers and sector of work, often moving from rural to urban areas and vice versa ${ }^{21}$. They claim living under stress, fear and insecurity related to lack of legal status, insufficient knowledge of the language, distance from their relatives and cohabitation with people they know very little and who are often old and sick. In most of the cases the first trip to Bulgaria takes place after three or five years, time necessary to legalize their situation in Greece and being able to circulate without any major difficulties inside and outside the country.

16 As time goes by, their presence becomes more visible in the public space and are created "meeting places", markets and restaurants where they can socialize and consume products coming from their country. Furthermore, they get to know the language better and, especially women, prefer to leave their "internal" domestic jobs (vûtreshna rabota) in order to work as freelance house-cleaners (vûnshna rabota), they hire an apartment and share it with one or more co-ethnics. One decisive factor stipulating these changes is the legalization of their residence in the "host" country and their passage from the status of "illegal" immigrants to that of "legal" (foreign) workers: "During the first years I was very afraid, I was not going out, we used to meet with two other friends of mine to a small public garden nearby in order to avoid being seen. We avoided the public transport, we were not speaking Bulgarian in public spaces ... now everything has changed, I am not afraid anymore!" 54 year-old Stefana remarks. All these changes signify a qualitative transformation of the migrant's presence in Greece.

17 Nevertheless, as a consequence of the lack, or loose implementation, of law regarding their residence and the conditions in the workspace, there is a great freedom of action in the labor market but also less security for both the employers and the workers. As most of them are involved in jobs where the relations with their employers are more personal -especially those who look after children and elderly people- trust and personal involvement are developed. It is indicative that finding a job through acquaintances is considered to assure both to the employer and to the employee a kind of guarantee:"My employers trust me, now they even give me the keys of their house. But I also behave myself well. Because everything is a matter of confidence" Rada, aged 55, remarks.

At the same time, the transactions with the state are most of the times synonymous to maltreatment, inefficiency and exploitation. To this perception contribute the experiences with the public services, a contact which most of the times is unfavorable to them. Many migrants believe for example that the health system they left in Bulgaria was much better compared with the Greek one, but they feel that nowadays "even this one has changed for the worstand became like the Greek one!" (Dana, aged 47). They refer to the long queues and to the waste of time in front of the desks of the services, or to the inefficiency of the employees. They all have faced difficulties to obtain the 
necessary documents for their legalization procedures and they are shocked by the Greek bureaucracy: "during my stay in Greece I have collected as many documents as for my entire thirty years life in Bulgaria" 32 year-old Dida notes. Some decide to hire a lawyer for dealing with all their transactions with the public services but they complain that they are often exploited instead of served. For example, they are demanded to provide huge amounts of money for small services or they are treated without the necessary seriousness: Greek lawyers talk to them impolitely, they don't take the time to listen to them, they are always busy when their clients call them for their affair.

The most serious complain and disappointment has to do with the hardships and lack of respect they face both from the public services and the civil servants. They are very critical about the latter "who get their salary from us but treat us like rubbish. Very few are polite and civilized" (Iva). They also feel that the Greek state is interested only in getting profit from them. For example, most of the time the work and residence permissions they get are expired: "we pay for our obligations and we give the money on time, but they (the civil servants) don't do their job properly, they only are interested in getting the money" Katia, aged 49, complains. Nonetheless, many migrants believe that this kind of treatment is not reserved to them specifically, but concerns the Greek citizens too. And although many declare themselves dissatisfied by the social services they use them systematically. They even adopt some attitudes of the local population. For example, Mariana made an important operation in a public hospital. She says: "I received my money from the social security but I knew that I had to give to the doctor who operated me some extra money (roushvet). This is a common secret in Greece". Others prefer to visit private doctors only, as many Greeks do: "if it is necessary I prefer to go to a private doctor. You go, you pay and have your job done, whilst in a public clinic you have to wait for months to have an appointment with a doctor!" Ivan, 33 years old, explains. In all cases, they perceive the contradiction between the strict legal framework and the weakness and malleability of the state regarding the application of the law as a feature of the Greek society concerning not only the immigrants but also the Greek citizens. They realize that the personified and unofficial character of the relation of both Greek citizens and immigrants to a weak institutional framework and a powerful bureaucratic mechanism is quite similar to the way the Bulgarian state functions, driving them to feel Greece more familiar and proximate with Bulgaria.

\section{Relations with the Bulgarian state and association with the co- nationals in Greece}

20 The above perceptions are interrelated to the images Bulgarian migrants have about the Bulgarian state and its representatives in Greece (mainly the embassy). Almost unanimously they have a very negative opinion about it, as well as for the Bulgarian Association in Athens ${ }^{22}$, as they consider that they both are indifferent to the real problems of Bulgarian citizens and do not care for helping them abroad: "the Greeks treat us better than the staff in our embassy. They think that they are installed in a throne and that all those who are behind the desk are a distant $22^{\text {nd }}$ category of people. I feel total disappointment" (Daniela, 38 years-old). This is the reason why most of them systematically avoid every possible contact with the above-mentioned institutions. For example, few assist the official celebrations organized by the Bulgarian embassy in collaboration with the Association in the 24 of May, Day of Cyril and Methodius. The great majority despises such events reacting to the lack of interest and support that 
they perceive from them: "we don't need parties and fiestas when we don't even have legal papers here" Dida remarks.

The church doesn't constitute either a pole of attraction or a meeting point for the Bulgarians in Athens, as it is the case with the Russian orthodox church or the Polish catholic church ${ }^{23}$ : "We, Bulgarians are not so religious (viarvashti)" 34 year-old Mariana notes. The ones who wish to attend the liturgy go to the Russian church or to Greek orthodox churches in the neighborhood they live. Some, especially older women, are influenced by the overall situation in Greece where many people go often to the church, and accompanying the older people they take care of, visit the church much more frequently than they used to do in Bulgaria. Others have joined the Pentecostal, Evangelical and other non-orthodox churches in Athens.

In a more general way, there is not a sense of "community" among the Bulgarians in Athens. As it doesn't exist any distinct neighborhood (most of them live either in the city center in mixed immigrant neighborhoods or they are dispersed in the city according to the places their employers are located), nor a shopping district (only some "ethnic" shops here and there in the center of Athens), there is an absence of a geographically or network-based ethnic community. In their free time, people socialize mainly in the Bulgarian restaurants or at the Bulgarian market in the center of Athens, in coffee shops and parks all around the capital. They also invite and organize feasts at home. Nevertheless, social networks are weak and neither serve any strategic purposes nor do they play any important political role ${ }^{24}$.

Most of our co-discussants declare having friendships almost exclusively with other Bulgarians ${ }^{25}$ and at the same time they speak in a very negative way for their compatriots: "when I see how some of us behave I am ashamed that I am Bulgarian" 38 yearold Daniela remarks."We Bulgarians are a little bit jealous one another (zavizdame se). Albanians are not like that. The gypsies neither. They might cheat one another but if you cheat one of them they will come and kill you. Whilst Bulgarians will ignore you and won't give you any help ... why should I have to associate with people who at least each word they state out of three is a lie?"42 year-old Galia makes a typical comment. Most of them met their coethnics in Athens through common acquaintances or whilst waiting in the long queues for their documents or, simply, by hearing them speaking Bulgarian in the bus or another public place: "I had never met as many Bulgarians from so many different corners of the country as I have met here" 45 year-old Rumiana explains.

\section{Performances of symbolic boundaries and redefinition of Bulgarian identity}

Except the relations with the Greek state, everyday interaction with natives contributes to the ambivalent sentiments and images that most Bulgarian migrants have of Greece. From the time of Fredrik Barth's seminal study on borders (1969), it has become quite commonsensical within anthropology that boundary maintenance involves complex symbolic processes of inclusion and exclusion that safeguard the "integrity" of the respective groups. This is more so in the case of Balkan identities, in the light of their historical background and today's population flows. As G. Tsimouris notes about Greece “migrants' identities, especially those who have Balkan origin (...), are shaped in the fissures of a framework of antagonist ethnocentric traditions" (2008b: 9). Since their 
formation in the $19^{\text {th }}$ century, both the Greek and the Bulgarian state have constructed their national identity at the base of antagonisms with the neighboring Others, a competition expressed and nourished first by the numerous Balkan conflicts and second by the cold War divisions. Both states have also lacked of a pluralist ideology, giving emphasis to assimilation and national homogenization rather than multiculturalism ${ }^{26}$. With the opening of the two countries to new migration flows the stereotypes about the Self and the Other are challenged. Thus, in this context are formed the ways in which Bulgarian migrants perceive Greeks and through the interaction with them reconsider their self-images and question or confirm their "Europeaness".

As there is not any physical Bulgarian community in Athens, most individuals have regular everyday contacts with their Greek neighbors, colleagues or employers. On the one hand, they recognize several common features between Bulgarian and Greek people: “We both are Balkan people, aren't we? ... A little bit savage (he laughs) ... A little bit Oriental (he laughs). This is not something negative for me. We both have something ... how could I explain, a kind of madness, a temperament (tamperamentni). We are not cold (studeni) like the Germans or the Austrians for example" Anton, aged 41, comments. They also refer to the common religious tradition "we are Christians, like you are" (Violeta, aged 49), although they consider Greeks to be much more religious than they are.

However, through their stay in Greece they develop a more critical view of the Greeks, related to the bad behavior and the lack of respect they often receive from them: "they look at me in some unfriendly way, as if I am an enemy, because I am a foreigner and have an accent. I would like them to look at me just like a human being" Stefana recalls. They believe that younger Greeks are more open as they are interested to learn about socialism as well as about the actual situation in Bulgaria, whilst elderly people are often more reserved and biased. For example, the latter often refer to the old territorial competitions between the two countries or deny tasting Bulgarian food, demanding from the Bulgarian domestics they hire to cook Greek food. What affects the migrants more is the stereotypical ideas many Greeks have about life in Bulgaria as quite "poor" and "underdeveloped" and their total ignorance about the Bulgarian history and the actual situation of the country: "What angers me more is when people here ask me whether during communism we had refrigerators, washing machines and other facilities, or even if we have such things today! What do they think, that we live like savages?" Daniela notes.

In addition, the new work relations initiated by migration contribute to the transformation of the participants' perceptions regarding their social status. Most of my informants note a reconsideration of hierarchy relations between the two countries after the end of the Cold War due to their economic inequalities. They remark that immigrants take all the jobs Greeks don't want to do any more, like -agriculturalworkers, house-cleaners, builders, and that this situation creates social differentiations. They criticize the moral and economic superiority that they feel that Greeks perform in relation to foreign workers. They also believe that until recently both Greece and Bulgaria were peripheral and poor countries and that in many aspects Bulgaria was in a better economic position than Greece: «Greeks don't treat us like equals. They have a short memory, as they don't remember any more that some years before they also were immigrants in Germany or Australia. Now they behave like bosses!" (Rumiana). Many explain how difficult their everyday life is and the social degradation that migration implied for them "I have 
worked as a teacher all my life long and here I came in my late forties to become a house-cleaner in a foreign country" Katia complains.

It becomes clear that due to Greece's economic development during the last decades Greeks can now perform new roles. As Lauth Bacas notes, "from potential migrants they turned into potential employers of migrants" (2002: 206) and this transformation process has important implications to the ways they reaffirm their social identities. Through their contacts with immigrants, Greeks develop a sense of superiority and "Europeaness". Nevertheless, Bulgarian migrants criticize this image as they consider that Greeks look for easy money, that they are lazy and wasteful: "you pass your time drinking coffees, eating out and spent a lot of money purposeless, just for pleasure" Rada remarks. These practices are in contrast with the economic strategies most migrants adopt, working double and triple jobs in order to save money and invest it for their children's education or for the construction, repairing or buying of property. This is the reason why Bulgarian migrants challenge the Greek image of the self as "successful" and "European": "You have become rich with foreign money and now you want us to respect and serve you" 40 year-old Valentin voices a typical comment. Furthermore it seems that these hierarchies are constantly in balance as in many occasions Bulgarians reverse the hegemonic images which Greek society fabricated of them. For example, Greece is seen in many ways as inferior compared with Bulgaria of the socialist era. They recall the achievements of their country in many domains of the public life, the standards of services that seem to have been much higher rather than in contemporary Greece, as for example the education or health system. In many cases, they also declare that they are not interested in getting the Greek nationality and that what is more important for them is the possibility to assure a legal status in the country. "Why should I look for a Greek passport? Now that we have entered the EU it has the same value with the Bulgarian one. The only thing I want is to have legal documents, to be able to live free in this country as in my own " 34 year-old Mariana comments.

\section{Representing "Europe" and the European Union}

Concerning the entrance of their country inthe EU, in contrast to the favorable opinion that most of their compatriots in Bulgaria express, Bulgarian migrants, in their majority, are much more skeptical and often they are against it: "I would prefer that we remain independent, like Switzerland or Norway, I don't know exactly which are these countries in the North, who have chosen not to enter. I personally disagree, but nobody asked my opinion" Violeta remarks. Many are very pessimistic about the situation in their country and consider that the entrance to the EU will not change anything to the positive direction: "I'm completely disappointed from Bulgaria. I think we will enter the EU next year, isn't it? Then the country will be evacuated. Every single person who has the opportunity will leave" notes Daniela. Also, most believe that nothing will change in their everyday life in Greece because of the integration of Bulgaria in the EU. Some others have not a clear idea and say they expect to see what will happen in relation to the enlargement in order to decide whether they will return or not.

For most of my co-discussants "Europe" seems to be an idealized and abstract entity, hearing many things about it but having few experiences. They remark that during their stay in Bulgaria EU policies affected very little their everyday life. They also argue, that for the moment, they do not notice any major impact in the life of their 
relatives in Bulgaria as a result of the country's attachment to the EU. Most of the time, they stress that the only tangible experience they had of the EU was the important problems they faced in their attempt to have access and free movement within the EU space. In view of such difficulties, they seem to reject a relation with a "Europe" with which they believe they share common values, but which treats them as different, and inferior, because of their economic inefficiencies. Considering themselves as members of Europe in cultural terms, they expect solidarity and assistance to their individual and national effort of economic and political transformation. Instead they see themselves placed at the bottom of the hierarchy of the European nations and treated in the same way as other immigrants from Asia or Africa which they perceive as distant and different "We are Europeans, but here we are treated just like all other immigrants" Dana makes a typical comment. This is the reason why they reject the partial European citizenship and legal rights that the EU enlargement implies and the new limits it demarcates between the "old" and the "new" Europe ${ }^{27}$.

In addition, many are very skeptical and consider European policies to be unfavorable for the smaller and less powerful European states, like Bulgaria. In several aspects, their experience from Greece drove them to become more reserved: "We will become like you. The prices will catch up in European levels whilst the salaries will remain Bulgarian" Vesselin, aged 31, comments. In a more general way, the experience of a country like Greece, who has benefited from the economical advantages of its participation to the European project but which did not achieve to fully adapt to the 'European' institutions, enforces an image of Europe's powerlessness and creates more doubts about the interest of adhering to it. At the same time, they foresee a future for their country similar to that of Greece and make of it an example with which they can compare and identify their country: "one day we can become like Greece, but we will never become like Britain or Germany" Iva notes. So Greece represents for many migrants not a model of what a European country is but a plausible model of what Bulgaria will become through its participation to the EU.

Concerning their plans for the future, no one can give a definite reply: "It is very difficult to foresee at this moment. During communism we were used to make long-term plans. This is no longer the case. World is now insecure" 34 year-old Lily says. In a more general way, their discourse is characterized by pessimism for the future: "I amnot at all optimist" Daniela says "I am hearing since long that the situation will get better, but I do not see any improvement. On the contrary, things are getting worse and worse. The difference between people in Bulgaria, between the poor and the rich, has become too obvious. Who can make me optimist? I only hope that things will get better formy children, although I doubt." As a result, Bulgarian migrants in Greece live in the present. With a lot of references to the past and few expectations or dreams for the future, they try to cope with the uncertainties and the unstable conditions that have followed the fall of socialism and the integration of Bulgaria to the contemporary, globalized world.

These perceptions explain to a large extent the fact that very few are planning their return to Bulgaria in the near future, especially among the younger ones. Disappointed by the Bulgarian state, and pessimistic of the future in Bulgaria, they face Greece as a country close to their country of origin and, at the same time, providing them with more favorable economic opportunities and better conditions of work and life in the present. Many note that they believe that jobs and conditions of life in other European countries are better than in Greece and that they, especially the younger ones, had 
envisaged moving towardsthe "West", namely countries like France, Germany, the UK or the States. But they admit that they finally stayed in Greece because after learning the language and after their struggle for legalization it was too hard for them to try all that once again in another place. As a result, although many of them migrated with the perspective to get back to Bulgaria some, especially those who have no family obligations, changed their minds and wish to establish themselves in Greece or to stay for a longer period of time, until they see the situation improving in Bulgaria.

\section{Conclusion}

\section{1}

irect experiences in Greece generated the reconsideration of the migrant's perceptions of the Greek society, which they consider as a "wealthy" and "democratic" one, but less "European" from other member-states of the EU, since "Europeaness" does not deal only with prosperity but also with the organization and the power of the state, as well as with the implementation of the law, domains which are less developed in Greece, exactly as it is the case of Bulgaria. As a consequence, the migration experience among Bulgarians comes to enforce the sense of proximity and familiarity between the two countries. This is the reason why they challenge the hierarchical relations developed between the Greeks and themselves through the process of migration. They question the construction of the Greek Self through the new work relations and the promotion of a "European" identity which opposes the Greeks as employers to the nonEuropean Others, and more specifically to the new Other which are the immigrants. Furthermore, they equally experience and wish to challenge the role of a "second category" member in the EU and reverse this position by claiming a neutral role and a European identity such as that of Switzerland or Norway whose belonging to "Europe" is not questioned even though they are not part of the EU.

As our ethnographic example has attempted to show, the new Greco-Bulgarian contacts through migration create new frontiers and new performances of power. Like many other European countries, Greece was ill prepared to shift from an emigration to an immigration country. It also lacks a pluralist ideology and has based the construction of its national identity to an ideal of "homogenization" and "purity", giving emphasis to assimilation rather than multiculturalism. In this context, the cross-cultural interaction between Greeks and immigrants leads to the intensification of social boundary maintenance. After all, disappointed from both the Bulgarian and the Greek state and reserved regarding the benefits they could get from their participation to the European project, Bulgarian migrants reject the hegemonic (Greek and EU) hierarchical 
representation about their migration and claim a place, both inside the Greek society and the "European family" as equal and legitimate members.

\section{BIBLIOGRAPHY}

Appadurai Arjun, 1991, "Global Ethnoscapes. Notes and Queries for a Transnational Anthropology”, in Fox R. (ed.), Recapturing Anthropology, Santa Fe, NM: School of American Research Press, 191-210.

Agelopoulos, Giorgos, 2007, "Opseis ton Anthropologikon Meleton tis Metanasteusis stin Ellada" (Aspects of anthropological studies on migration in Greece), O Politis 158, 23-27.

Angelidou Aliki, 2008, "Becoming the breadwinners: Economic practices and gender identities among Bulgarian female migrants in Athens", in To Vima ton Koinonikon Epistimon (The Tribune of Social Sciences), 18p., forthcoming.

Bakic-Hayden Milica, 1995, "Nesting Orientalisms: The Case of Former Yugoslavia”, Slavic Review, 54(4), 917-931.

Barth Frederic, 1969, "Introduction”, in Barth F. (ed.), Ethnic Groups and Boundaries: The Social Organization of Culture Difference, Universitetsforlaget, Oslo, 9-38.

Brah Avtar, 1996, Cartographies of Diasporas, London, Routledge.

Brettell Caroline, 2003, Anthropology and Migration: Essays on Transnationalism, Ethnicity and Identity, Walnut Creek, Lanham, New York, Oxford, Altamira Press.

Clifford James, 1994, “Diasporas”, Cultural Anthropology, 9(3), 302-338.

Cohen Robin, 1997, Global Diasporas: An Introduction, London, UCL Press.

Ditchev Ivaylo, 2008, “Mobile citizenship?”, Eurozine

(http://www.eurozine.org/articles/2008-06-27-ditchev-en.html).

Glick Schiller Nina, Basch Linda \& Szanton Blanc Christina (eds.), 1992, Towards a Transnational Perspective on Migration: Race, Class, Ethnicity, and Nationalism Reconsidered, New York, New York Academy of Science.

Glick Schiller Nina, Basch Linda \& Szanton Blanc Christina (eds.), 1994, Nations Unbound: Transtational Projects, Postcolonial Predicaments, and Deterritorialized Nation-States, Basel, Gordon and Breach.

Green Nancy, 2002, Repenser les migrations (Rethinking migrations), Paris, Presses Universitaires de France.

Karamihova Margarita, 2003, Da zhiveesh tam, da se sûnouvash tuk. Emigratsionni protsesi v nachaloto na XXI vek (Living there, dreaming of yourself here: Emigration processes at the beginning of the 21st century), Sofia, IMIR.

Kearney Michael, 1995, "The local and the global: The anthropology of Globalization and Transnationalism", Annual Review of Anthropology, 24, 547-565. 
Kearney Michael, 2004, "The classifying and value-filtering missions of borders", Anthropological Theory, 4(2), 131-156.

Kivisto Peter, 2001, "Theorizing transnational immigration: a critical review of current efforts", Ethnic and Racial Studies, 24(4), 549-577.

Kofti Dimitra (forthcoming), “Acquiring power across the borders: Greek tourists in Bulgaria”, in Anastassakis O., Bechev D. \& Vrousalis N. (eds.), Greece and the Balkans: Memories, Conflict and Exchange, Cambridge, Cambridge Scholars Press.

Krasteva Anna (ed.), 2005, "Bûlgarskiyat imigratsionen fenomen" (The Bulgarian immigration phenomenon), in A. Krasteva (ed.), Imigratsiyata v Bûlgaria (Immigration in Bulgaria), Sofia, IMIR, 7-18.

Lauth Bacas Jutta, 2002, "Greece and its New Immigrants: Features and Consequences of the Recent Immigration to Greece”, Ethnologia Balkanica, 6, 197-208.

Labrianidis Lois \& Lyberaki Antigoni, 2001, Albanoi metanastes sti Thessaloniki: Diadromes euimerias kai paradromes dimosias eikonas (Albanian migrants in Thessaloniki: Itineraries of prosperity and oversights of the public images), Thessaloniki, Paratiritis.

Levitt Peggy, 2004, “Transnational Migrants: When 'Home' Means More Than One Country”, in http://www.migrationinformation.org/Feature/print.cfm?ID=26.

Markova Evgenia, 2001, “Oi Voulgaroi stin Ellada” (Bulgarians in Greece), in Marvakis, A., Parsanoglou, D. and Paulou, M. (eds.), Metanastes stin Ellada (Migrants in Greece), Athens, Ellinika Grammata, 355-358.

National Statistical Service of Greece, Stoiheia Apografis Plythismou 2001 (Population Census Data 2001), (http://www.statistics.gr).

Neofotistos Vasiliki, 2008, “'The Balkans' Other Within': Imaginings of the West in the Republic of Macedonia", History and Anthropology, 19(1), 17-36.

Nitsiakos Vassilis, 2003, Martyries Albanon Metanaston (Testimonies of Albanian Migrants), Athens, Odysseas.

Papataxiarchis Euthymios (ed.), 2006, Peripeteies tis eterotitas: I paragogi tis politismikis diaforas sti simerini Ellada (Diversity's adventures: Production of cultural diversity in today's Greece), Athens, Alexandreia.

Todorova Maria, 1997, Imagining the Balkans, New York, Oxford, Oxford University Press.

Tsimouris, Giorgos, 2008a, “Anthropologikes prosegiseis tis metanasteusis sti metapolemiki Ellada: orismenes ypotheseis gia mia argoporimeni shesi" (Anthropological approaches on migration in postwar Greece: some hypothesis for a delayed relationship), in Gefou-Madianou D. (ed.) Opseis tis Syghronis Anthropologikis Ereunas stin Ellada (Aspects of Contemporary Anthropological Research in Greece) Athens, Ellinika Grammata (under publication).

Tsimouris Giorgos, 2008b, “Fadasiakes geografies kai diethnikes metanasteutikes koinotites: Neo fainomeno i palio fainomeno se synthikes ysterou kapitalismou?" (Imagined Geographies and transnational migration communities: A new phenomenon or an old phenomenon in conditions of late capitalism?), in Spyridakis M. (ed.) Metasximatismoi tou horou: Diepistimonikes prosegiseis kai ereunitikes praktikes (Transformation of the space: Interdisciplinary approaches and research practices), Athens, Nisos (under publication).

Vertovec Steven, 1999, "Conceiving and researching transnationalism”, Ethnic and Racial Studies, 22(2), 447-5462. 
Vertovec Steven \& Cohen Robin (eds.), 1999, Migration, diasporas and transnationalism, Cheltenham, Northampton, Edward Elgar.

Wimmer Andreas \& Schiller Glick Nina, 2002, "Methodological nationalism and beyond: nationstate building, migration and social sciences", Global Networks, 2(4), 301-334.

Wolff Larry, 1994, Inventing Eastern Europe: The Map of Civilization on the Mind of the Enlightenment, Stanford, California, Stanford University Press.

\section{NOTES}

1. With important contributions (among others) the works of Glick Schiller, Basch \& Szanton Blanc 1992 and 1994, Kearney 1995, Vertovec 1999, Kivisto 2001 or Levitt 2004.

2. It is also related to new theoretical advances such as the criticism of "methodological nationalism" (Wimmer \& Schiller 2002) and of the binary (national) frames of thinking the migration, the focus on "deterritorialisation" (Appadurai 1991: 196) of social relations and identities or the interest about the subjective meanings of displacement.

3. According to the last census of 2001 , about $70 \%$ of the immigrants actually presentin Greece come from the above-mentioned countries (National Statistical Service of Greece).

4. For the construction of the "European" Self in relation to the "Balkan" or "Eastern" Others see for example the work of M. Todorova (1997) and L. Wolff (1994). Also, for the ways Southeastern Europeans imagine themselves in relation to the "West" see M. Bakic-Hayden (1995) and V. Neofotistos (2008).

5. For the renegotiations of stereotypes and power relations of Greek tourists through the crossing of the Greek-Bulgarian border see the analysis of D. Kofti (forthcoming).

6. For a critical review of anthropological studies of migration in Greece see Agelopoulos (2007) and Tsimouris (2008a).

7. This presentation is based on material collected during my participation to the research program PYTHAGORAS II "Multiculturalism and migration in Greece: Ethnic groups, identities, representations and practices in the era of globalisation", conducted by the Department of Social Anthropology, Panteion University and co-financed by the European Union and the Greek Ministry of Education.

8. Athens and Marathonas (region of Attica) are characterized by one of the most important concentrations of immigrants in the country. Mediterranean Migration Observatory, Panteion University, Statistical Data on immigrants in Greece. An Analytic Study of Available Data and Recommendations for Conformity with European Standards, Athens, IMEPO, 2004, p. 6 (http:// www.mmo.gr/pdf/general/IMEPO_Final_Report_English.pdf).

9. The features and character of migrants' networks and their relation to space have not been considered as a priori given, but as one of the questions included at the research agenda. The research started from concrete individuals and has followed them in their everyday movements in order to investigate their social relations and the degree of their "territorialisation". Interestingly, although this research was conducted in two places with different social features (the urban area of Athens and the 'mixed' or semi-urban area of Marathonas) and althoughI spoke to persons from both urban and rural areas in Bulgaria, I have not noticed any important differences regarding their representations and views. Actually such a rural/urban divide has proved inaccurate in my analysis since many of my co-discussants often move from one to the other while changing places of work and/or residency.

10. For some recent studies on migration in Greece see Labrianidis \& Liberaki (2001), Nitsiakos (2003), Papataxiarhis (2006) and in Bulgaria Karamihova (2003), Krasteva (2005) and Ditchev (2008). 
11. The Bulgarians represent $5 \%$ of the registered immigrant population, whilst the Albanians 55,6\%, (Mediterranean Migration Observatory, op. cit., p. 5).

12. Bulgarian migration to Greece became massive after 1997 , when the country encountered a deep political and economic crisis which pushed many people to seek for better living conditions outside Bulgaria.

13. According to the last census of 2001 (National Statistical Service of Greece) $60 \%$ of the immigrants are women. Nevertheless, the above picture does not concern the totality of Bulgarian migrants in Greece. During my research I realized that there are many families as well as many individuals with various educational levels and from various backgrounds who study, work and live nowadays in Greece. So I approach the migrants as a heterogeneous and polyphonic rather than a homogeneous, compact and stereotypical category. My research has focusedmostly on women informants not only because of their quantitative over-representation among Bulgarian migrants, but mostly in order to cover a big gap in the study of recent migrations in Greece, which is the study of the role of gender to migratory processes. Although this paper does not focus on gender issues it was important to mention that the majority of my informants have been women. For an anthropological analysis of the gender aspects of Bulgarian migration in Greece see also Angelidou (2008).

14. E. Markova 2001.

15. For the values created as a consequence of the inequalities between the two sides of the borders see the analyses of N. Green (2004) and M. Kearney (2004).

16. It is worth noting that these perceptions are already different from those I had collected during the fieldwork for my PhD dissertation in Bulgaria, in the mid-1990s, when the economic crisis in Bulgaria was just in its beginning and the mass emigration had not started yet. At that time, there was an important lack of information and images about Greece, which was considered as a culturally similar country to Bulgaria as well as equally peripheral and weak in terms of international political power. However, socialist Bulgaria was described as more successful in terms of technology and economic growth. These antagonistic and to a certain extent despising images were, to my opinion, related to the stereotypes the communist propaganda had disseminated during socialism about the "capitalist" neighbour.

17. Most of them have learned the language in their place of work, in their everyday discussions with their employers and colleagues or by watching television, whilst very few have taken any courses. As a consequence, after some years of stay in the country they speak more or less fluently but very few know how to write or read in an elaboratedway.

18. Initially they moved directly form Bulgaria to Greece with a tourist visa. But since 2001, when the Shenghen visa restrictions were abolished for Bulgarian citizens who could then travel and stay without any visa up to three months to any country of the EU, the controls on the northern Greek borders became stricter. For this reason many migrants followedlonger itineraries (through Serbia, Hungary, Austria, Italy or Serbia, Croatia, Slovenia and Italy), in order to have easier access through the less controlled Greek-Italian border. In this case also it was the private "tourist" companies that organized the trip and the official procedures. After 2007, entrance to Greece is not restricted any more to Bulgarians as EU citizens. But the

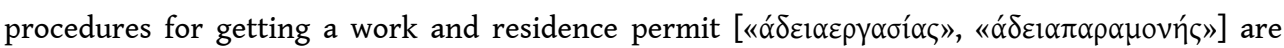
still complicated and expensive.

19. As private domestics and cleaning ladies they initially work without official documents and without social security and as the time goes by they obtain their legal documents and pay social security. Employers are more reluctant to pay any social security to their employees in taverns and bars.

20. The procedure of legalization started relatively late, in the late 1990s, almost a decade after the first massive arrival of immigrants in Greece. 
21. This temporariness is also expressed in the measures adopted by the Greek state: for example the work and residence permits have to be regularly actualized after their first edition.

22. This is the most important organization of Bulgarian migrants in Athens, assembling some of the most educated individuals and trying to cope with different questions concerning the every day life in Greece, such as the organization of Greek language courses or the provision of information about the legalization procedures. However, most of my co-discussants complain for its inefficacy and lack of organization.

23. The first Bulgarian church in Athens has been recently established.

24. The most significant activity of Bulgarian associative networks is the publication of four journals in Bulgarian language destinated to the migrants, providing them with practical information about everyday life and about the legalization of their status in Greece.

25. They also claim some friendships or relations with Greeks but very rarely with migrants of another nationality.

26. For a series of critical analyses of the specific modes of construction of the relation between Nation and State in the Greek and Balkan case through special focus on the study of minorities and migration phenomena in contemporary Greece, see the works of the interdisciplinary Minority Groups Research Center (KEMO) (www.kemo.gr).

27. For example, in their effort to avoid massive migrations from the former socialist countries, many "older" member-states of the EU, Greece included, have taken some transitory measures limiting the free access to work and residence in their territory for citizens coming from the "new" member-states.

\section{ABSTRACTS}

This paper deals with the new increasing trans-border movements between two neighboring countries that until very recently were separated not only by a national but also by a European border. More specifically it explores the perceptions Bulgarian migrants have of "Greece" and "Europe" during their daily interactions with their Greek employers, civil servants and neighbors. Emphasis is placed upon the reconsideration of the images migrants used to have before their arrival to Greece through the experience of daily life there. Is also examined the impact of these representations on the migrants' ideas about the EU and the negative attitude that most of them adopt towards the ascension procedure. Last call of attention is for the diverse meanings of "Bulgarian identity" that are activated through the migration process as well as for the new power relations involving both the newcomers and the Greeks.

\section{INDEX}

Geographical index: Grèce, Athènes

Mots-clés: Bulgares, Migrations 


\section{AUTHOR}

\section{ALIKI ANGELIDOU}

Dr. Aliki Angelidou is lecturer in Social Anthropology at the Department of Social Anthropology, Panteion University, Athens. She completed her PhD in Social Anthropology at the Ecole des Hautes Etudes en Sciences Sociales, in Paris, exploring the socio-economic transformations in post-socialist rural Bulgaria. Currently, she carries out research on migration and multiculturalism in Athens, with special focus on migrants from former Soviet Union and East European countries, and on the elites' mobility in the Balkans. Her recent publications include : "Becoming the breadwinners : Economic practices and gender identities among Bulgarian female migrants in Athens", in : To Vima ton Koinonikon Epistimon (The Tribune of Social Sciences), 18p. (forthcoming) ; "Returning to Cooperation: Production, Consumption and Identities in Postsocialist Rural Bulgaria", in : V. Nitsiakos et als (eds.), Balkan Border Crossings : First Annual of the Konitsa Summer School, Munster : LIT-Verlag, 2008, p.126-176; «Identités en transition : communisme agraire et appartenance locale dans un village bulgare post-communiste », Divinatio, 25, Spring-Summer 2007, p.139-160.

malangel@panteion.gr 